University of Wollongong

Research Online

Faculty of Social Sciences - Papers (Archive) Faculty of Arts, Social Sciences \& Humanities

2013

Who cares wins: The role of local news and news sources in influencing community responses to marine protected areas

Michelle Voyer

University of Technology, Sydney

Tanja Dreher

University of Wollongong, tanjad@uow.edu.au

William Gladstone

University of Technology, Sydney

Heather Goodall

University of Technology, Sydney

Follow this and additional works at: https://ro.uow.edu.au/sspapers

Part of the Education Commons, and the Social and Behavioral Sciences Commons

Research Online is the open access institutional repository for the University of Wollongong. For further information contact the UOW Library: research-pubs@uow.edu.au 


\title{
Who cares wins: The role of local news and news sources in influencing community responses to marine protected areas
}

\author{
Abstract \\ Mass media is a key tool by which environmental interventions, such as Marine Protected Areas (MPAs) \\ are communicated to the public. The way in which local news outlets present and explain MPAs to local \\ communities is likely to be influential in determining how they respond to the proposal. In particular the \\ tendency of news media to focus on areas of conflict and dispute ensures ideology and politics play a \\ central role in reporting of MPA proposals, often simplifying debate into an 'us versus them' or 'fishers \\ versus conservationists' ideological conflict. This can lead to the outright rejection of an MPA or \\ undermine acceptance of the park within local communities. The media coverage of two marine parks in \\ NSW, Australia was compared to determine the way in which news presented the parks to each \\ community and how this may have influenced public acceptance of the parks. In particular the study \\ examined the role ideology and politics played in the news coverage of each park by investigating the way \\ in which the news was framed and the positions of key media spokespeople. Media coverage of the \\ Batemans Marine Park appears to have been highly politicised and heavily influenced by the strong \\ convictions of a small handful of prominent spokespeople. By way of contrast media coverage of the Port \\ Stephens Great Lakes Marine Park was more nuanced and drew from a wide range of sources. This \\ research provides insight into how areas of conflict could be reframed as opportunities that enhance MPA \\ planning exercises and highlights how ideology can help shape community sentiment. Acknowledging the \\ role of ideology in contested areas such as these allows for the development of strategies that can \\ accommodate as well as moderate its influence. These strategies may include the incorporation of \\ 'bottom up' approaches into MPA planning, the promotion and support of a range of voices within the \\ community, and seeking out and building upon common ground and shared values.
}

\section{Keywords}

local, role, wins, protected, cares, marine, responses, community, influencing, sources, who, news, areas

\section{Disciplines}

Education | Social and Behavioral Sciences

\section{Publication Details}

Voyer, M., Dreher, T., Gladstone, W. \& Goodall, H. (2013). Who cares wins: The role of local news and news sources in influencing community responses to marine protected areas. Ocean and Coastal Management, 85 (Part A), 29-38. 


\title{
Who cares wins: the role of local news and news sources in influencing community responses to marine protected areas
}

\author{
Michelle Voyer, Tanja Dreher, Heather Goodall, William Gladstone
}

Citation: Voyer, M., Dreher, T., Gladstone, W. \& Goodall, H. 2013, 'Who cares wins: The role of local news and news sources in influencing community responses to marine protected areas', Ocean \& Coastal

Management, vol. 85, Part A, pp. 29-38

\begin{abstract}
Mass media is a key tool by which environmental interventions, such as Marine Protected Areas (MPAs) are communicated to the public. The way in which local news outlets present and explain MPAs to local communities is likely to be influential in determining how they respond to the proposal. In particular the tendency of news media to focus on areas of conflict and dispute ensures ideology and politics play a central role in reporting of MPA proposals, often simplifying debate into an 'us versus them' or 'fishers versus conservationists' ideological conflict. This can lead to the outright rejection of an MPA or undermine acceptance of the park within local communities. The media coverage of two marine parks in NSW, Australia was compared to determine the way in which news presented the parks to each community and how this may have influenced public acceptance of the parks. In particular the study examined the role ideology and politics played in the news coverage of each park by investigating the way in which the news was framed and the positions of key media spokespeople. Media coverage of the Batemans Marine Park appears to have been highly politicised and heavily influenced by the strong convictions of a small handful of prominent spokespeople. By way of contrast media coverage of the Port Stephens Great Lakes Marine Park was more nuanced and drew from a wide range of sources. This research provides insight into how areas of conflict could be reframed as opportunities that enhance MPA planning exercises and highlights how ideology can help shape community sentiment. Acknowledging the role of ideology in contested areas such as these allows for the development of strategies that can accommodate as well as moderate its influence. These strategies may include the incorporation of 'bottom up' approaches into MPA planning, the promotion and support of a range of voices within the community, and seeking out and building upon common ground and shared values.
\end{abstract}

\section{Introduction}

In an age of globalisation many of the environmental campaigns fought at a local level have links with global environmental crises, such as climate change, deforestation, water shortages, and biodiversity loss (Cottle, 2011). Many of these campaigns rely heavily on collective action across a multitude of jurisdictions around the world, with global campaigns dependent on the success of multiple local scale actions. Yet the individual success of these global campaigns depends significantly on local conditions, particularly community and political support (Lundquist and Granek, 2005, Wood et al., 2008, Robin, 2012, Voyer et al., 2013b).

Marine Protected Areas (MPAs) are an example of a highly contested conservation tool. International agreements, particularly the Convention of Biological Diversity, commit signatories to a system of MPAs covering between 10 and 30\% of their marine habitats by 2012, recently extended to 2020 . Declaration of such areas is therefore vigorously pursued globally but is meeting significant resistance at a local level (Wescott, 2006, Weible, 2008, Banks and Skilleter, 2010, Carneiro, 2011). Resistance from the public has led to the failure or delay of many attempts to establish MPAs throughout the world and conflict is often a feature of MPA planning processes (Fiske, 1992, Wolfenden et al., 1994, 
Agardy et al., 2003, Weible, 2008, Voyer et al., 2012). Driving the development of international MPA targets has been large scale loss of marine biodiversity and habitat, the collapse of a number of global fisheries as well as the increasing and insidious threat of climate change (Spalding et al., 2010, McCay and Jones, 2011). These threats are conceptualised on a global scale but may not be immediately visible or apparent to communities living in the areas in which the MPAs are proposed (Voyer et al., 2013a). In situations such as these, the way in which the value and purpose of MPAs is presented and explained is likely to be crucial to harnessing community support and minimising conflict. Undoubtedly one of the key tools by which communities are informed, educated and engaged in MPA planning processes is the media, and in particular local news media (Dikou and Dionysopoulou, 2011).

Access to the news media is a powerful means of influencing community attitudes and political outcomes (Gitlin, 1980, Ericson et al., 1989, Entman, 1993, Cottle, 2000, Lester, 2010). In the case of environmental interventions, such as MPAs, local media is a key conduit through which the public is informed of its necessity or value as well as being an important forum for engaging stakeholders in participation exercises (Compas et al., 2007, Dikou and Dionysopoulou, 2011). Criticism of global and local media coverage is common. Most often it is accused of bias in its reporting of environmental issues (Boykoff and Boykoff, 2004, van Vuuren, 2009). In addition reporting of interventions such as the declaration of MPAs is seldom placed within the global context that gives rise to a declaration. Instead it tends to focus on the conflict between opposing stakeholder groups (Ericson et al., 1989, Compas et al., 2007, Lester, 2010, Baysha and Calabrese, 2012).

Central to debates on media bias is the role of 'media frames'. Media frames are the way news media is constructed, organised or presented, emphasising some aspects while excluding or de-emphasising others (Gitlin, 1980). Media framing can be defined as:

Selecting and highlighting some facets of events or issues, and making connections among them so as to promote a particular interpretation, evaluation and/or solution....The words and images that make up the frame can be distinguished from the rest of the news by their capacity to stimulate support or opposition to the sides of a political conflict. (Entman, 2004)

Attention to news frames emphasises not merely what a story is about, but rather how that story is told. Just as a window focuses attention on only one aspect of the landscape, frames call attention to some aspects of a news story while simultaneously directing attention away from other aspects. Frames can therefore be defined not just by what they include but also what they exclude (Entman, 1993).

Lakoff (2010) contends that political ideologies are characterised by a series of frames which are strengthened and normalised through repetition. Cognitive science has demonstrated that simply informing people of the 'facts' is not enough to convince them of appropriate responses. In fact, people are primarily motivated by their own system of frames mostly driven by unconscious and emotional 'logic' and the 'facts must make sense in terms of their system of frames, or they will be ignored' (Lakoff, 2010). Aligning particular policy or management positions with ideology therefore is not uncommon in news media. Environmental causes are often seen as the domain of progressive parties, while conservative ideologies are more commonly associated with resistance to environmental actions (Lakoff, 2010). This is as true for local news media as it is for regional or national outlets, albeit on a smaller scale. In a study on the influence of local media on community involvement in local politics, Scheufele et al (2002) indicated that 'both the direction and extremity of ideological beliefs were related to the strength with which respondents held their attitudes on a local issue'. This 
is particularly significant in instances in which detailed scientific or technical understanding is required to inform community opinion, as is the case in many environmental debates. In these instances it is common for members of the community to look to trusted opinion leaders, who have a shared set of values and ideals in order to assist them form their judgement (van Vuuren, 2009). Therefore the way in which MPAs are presented to the community, and in particular the role of ideology in media reporting, is of crucial importance in influencing acceptance by the community. Media coverage which emphasises ideological differences may be influential in undermining support, particularly in communities in which ideological conflict is already apparent, by further galvanising support or opposition for a local issue along ideological or political lines. Alternatively if MPA proposals tap into shared value systems and beliefs within that community then it is more likely to garner community support (Ward and van Vuuren, 2013).

This paper explores the role of local print media in influencing community responses to two marine parks in New South Wales (NSW), Australia where community reactions to highly similar proposals differed significantly. It aims to determine the way in which news of the parks was presented to each community and how this may have influenced public acceptance of the parks. In particular the study examines the role ideology and politics played in the news coverage of each park. While two discreet local level case studies in NSW, Australia were selected the findings are relevant to any MPA process which attempts to engage the public or attracts significant media attention. The paper begins by examining the nature of the coverage of each of the marine parks, including the question of whether coverage was 'balanced' or 'biased', as well as how news of the parks was framed. The analysis included letters to the editor as they serve an important function in giving members of the public a voice, particularly in local media where it is common for newspapers to publish the overwhelming majority of the letters they receive (Wahl-Jorgensen, 2006). The paper then goes on to explore the role of news sources, who play an important role in shaping how issues are considered and viewed, emphasising the relative importance of some views over others (Ross, 2006). The motivations, agendas and aspirations of the sources selected for media prominence is therefore essential for an accurate understanding of the way in which a news story is reported (Schlesinger, 1990, Lester, 2010). By looking at news articles and letters to the editor in papers covering each marine park prominent media sources and letter writers were identified. These members of the community were then interviewed to establish the goals, motivations and values which drove them to play an active part in the media campaigns around the marine parks. Specifically the research sought to answer the following questions:

1. How were supportive and critical arguments in relation to the marine parks presented to the local community and by whom, and did this differ across the two parks?

2. Who was active in the media around the marine parks and what motivated their involvement, and did this differ across the two parks?

\section{Methods}

\subsection{Study areas}

In December 2005 and April 2006 the NSW State Government established the Port Stephens-Great Lakes Marine Park (PSGLMP) on the mid north coast and Batemans Marine Park (BMP) on the south coast. NSW marine parks are large 'multiple use' MPAs zoned for different types of use. The highest level of protection within a NSW marine park is the 'Sanctuary Zone' or 'no take' zone where all forms of fishing, extraction of marine life, and damage to habitat are prohibited. This zone type is the most restrictive and is therefore often the most controversial aspect of marine park planning. The process by which these parks were gazetted and zoned was virtually identical and conducted 
concurrently. Both parks are roughly the same size, have similar levels of Sanctuary Zone protection, and had extensive public consultation processes. Despite the similarities each community responded differently to their local marine park. The BMP generated significantly more submissions from recreational fishing interests (mostly form letters calling for the abolition of all Sanctuary Zones) than the PSGLMP, while the PSGLMP generated significantly more submissions from conservation interests, supporting the expansion of Sanctuary Zones within the park (Voyer et al., 2013a).

The declaration and planning associated with each marine park was conducted during the lead up to the March 2007 state government election and the parks were significant election issues in the relevant electorates at that time and then again in the following state election in 2011. Opposition to the BMP continues to this day and many of its key opponents, alongside other NSW fishers, have remained engaged in actively lobbying the State government for changes to marine park management throughout the state and for zoning plans to be overturned or reviewed. This lobbying has resulted in two public inquiries into marine parks in the last four years, the passing of a moratorium on new marine park declarations and the reversal of zoning plan changes made to two NSW parks prior to the last state election (Hodgkinson and Parker, 2011). The most recent changes include the establishment of the NSW Marine Estate Management Authority to guide management of the entire NSW marine estate, including a review of zoning arrangements for all NSW marine parks (NSW Government, 2013). Controversially, they also issued an amnesty over line fishing from all coastal beaches and headlands within NSW marine park Sanctuary Zones, effectively allowing recreational fishing in these Sanctuary Zones. As part of this package of reforms, the BMP was announced one of the first parks in which zoning plans would be reviewed (Gorton, 2013). The history of NSW marine parks therefore indicates that community opposition can be a strong driver of political action in relation to MPAs even following the finalisation of their boundaries and management arrangements.

\subsection{Study methods}

A mix of quantitative and qualitative techniques was used to examine the role of the media in the debate over the PSGLMP and the BMP. The study focused primarily on print media, namely local newspapers within the general marine park area, between January 2005 (1 year prior to the announcement of the proposed declaration of the marine parks) and December 2009 (four years after the announcement). There are six local newspapers that have circulation areas that incorporate the study areas and all six were included in this study (Table 1). Other forms of media relevant to the study areas included regional radio and television stations as well as a number of major and regional newspapers. While these outlets covered the marine parks to varying extents the decision was made to focus specifically on local newspapers because they provided regular and ongoing coverage which was immediately relevant to the readership. Print media was also chosen since it is a readily available and accurate archival data source which can provide an insight into issues on a local scale not provided through these other forms of more widely circulated media. Print media has been recognised as the most widely used source of local news in regional areas and has a 'agenda setting' function in the wider news media (van Vuuren, 2009). Articles were sourced from online media archives. Data gaps were filled from media files held in each marine park government office and state library archives. 
Table 1. Local newspapers within PSGLMP and BMP marine park areas

\begin{tabular}{|l|l|l|l|l|}
\hline Park & Newspaper & Circulation* & Readership* & Frequency \\
\hline PSGLMP & Newcastle Herald & $48000+$ & $\begin{array}{l}\text { Mon-Fri 131000 } \\
\text { Sat 186000 }\end{array}$ & Mon-Sat \\
\cline { 2 - 5 } & Great Lakes Advocate & 5862 & 18028 & Weekly \\
\cline { 2 - 5 } & Port Stephens Examiner** & 28123 & 28123 & Weekly \\
\hline \multirow{3}{*}{ BMP } & Bay Post/Moruya Examiner & 3769 & 8589 & Bi-weekly \\
\cline { 2 - 5 } & Narooma News & 2341 & 6259 & Weekly \\
\cline { 2 - 5 } & Milton Ulladulla Times & 5050 & 15814 & Weekly \\
\hline
\end{tabular}

*Readership figures from http://www.ruralpresssales.com.au/index.asp (accessed 03/2011) or http://www.adcentre.com.au/ (accessed 03/2011)

** Free newspaper

Content analysis of news stories and letters to the editor was conducted to determine whether they indicated a predominately supportive, critical, mixed or neutral message about the marine park (Wolch et al., 1997, Boissonneault et al., 2005, Compas et al., 2007, van Vuuren, 2009). In addition the role of the primary definer in each news article was classified according to stakeholder group. Primary definers were classified as those spokespeople who set the agenda or theme of the article (Hall et al., 1978). In most cases the primary definer was listed as the spokesperson first quoted or referred to in the article. However in some circumstances it was the spokesperson given the greatest exposure or prominence in the article (ie the most 'copy').

Finally a series of semi-structured interviews were conducted with prominent media spokespeople identified during the analysis of news articles and letters to the editor. Interviews specifically related to the media coverage were limited to the most active media spokespeople in each park but were conducted as part of wider study into social acceptance of the two marine parks, which involved over 50 interviews with a range of stakeholders. These interviews often touched on issues relating to the media and provided context to this study (see Voyer et al., 2013b). Interview subjects relevant to the media analysis component of this study were selected according to their proclivity as a letter writer or their associations with the key interest groups featured in the news media. Table 2 details the number of interview participants, their activity in the media during the study period and the stakeholder group they represented ${ }^{1}$. In order to protect the anonymity of the participants links with specific organisations are not made clear.

\footnotetext{
${ }^{1}$ The analysis of media content detailed below revealed a far greater concentration of sources in the BMP than the PSGLMP meaning there was more even coverage across a greater diversity of sources in the PSGLMP. This made source selection for the purpose of the research more problematic in the PSGLMP given no dominant spokespeople emerged from the analysis. It also resulted in the smaller number of interviews within the PSGLMP.
} 
Table 2. Spokespeople selected for interview and their media prominence in local papers between 2005-2010

\begin{tabular}{|l|l|l|l|l|}
\hline Marine Park & Stakeholder group/interviewees & Articles & Letters to the editor \\
\hline \multirow{3}{*}{ BMP } & \multirow{2}{*}{ Recreational fishing } & 1 & 17 & 2 \\
\cline { 3 - 5 } & & 2 & 23 & 40 \\
\cline { 3 - 5 } & 3 & 1 & 27 \\
\cline { 3 - 5 } & Conservation & 1 & 10 & 12 \\
\cline { 3 - 5 } & & 2 & 6 & 19 \\
\cline { 3 - 5 } & & 3 & 6 & 2 \\
\hline \multirow{3}{*}{ PSGLMP } & Recreational fishing & 1 & 7 & 1 \\
\cline { 3 - 5 } & & 2 & 11 & 2 \\
\cline { 2 - 5 } & Conservation & 1 & 5 & 11 \\
\hline
\end{tabular}

The interview participants were asked a range of questions relating to their use of the marine park, what they enjoyed about living in the local area, what they considered to be the main threats to the area, how they saw their role in the local media and what key messages they sought to present through the media during and since the marine park planning process. All interviews were logged and returned to the interview participants for checking. Analysis of the interviews was conducted using a thematic analysis approach whereby repeated coding, sorting and categorising was conducted using Nvivo qualitative analysis software (Miles and Huberman, 1994, Maxwell, 2005, Creswell, 2009). This was largely done through the examination of the dominant coding 'references', or the codes which were most prominent in the interviews, as a way of measuring the importance of key concepts to the interview participants.

\section{Results}

\subsection{News articles}

In total 547 articles were found - 312 in BMP newspapers and 235 in PSGLMP newspapers. Given the differences in publication frequency of the papers studied the number of articles and letters were standardised. This resulted in a standardised figure of 401 articles of which $139(35 \%)$ were published in the PSGLMP papers and $262(65 \%)$ were published in the BMP. Maximum media coverage occurred during 2006 when the zoning plans for each park were being developed (Figure 1). In both parks critical articles dominated in the year in which planning was undertaken (2006) but articles tended to be more balanced with supportive and neutral articles in the remainder of the study period. 


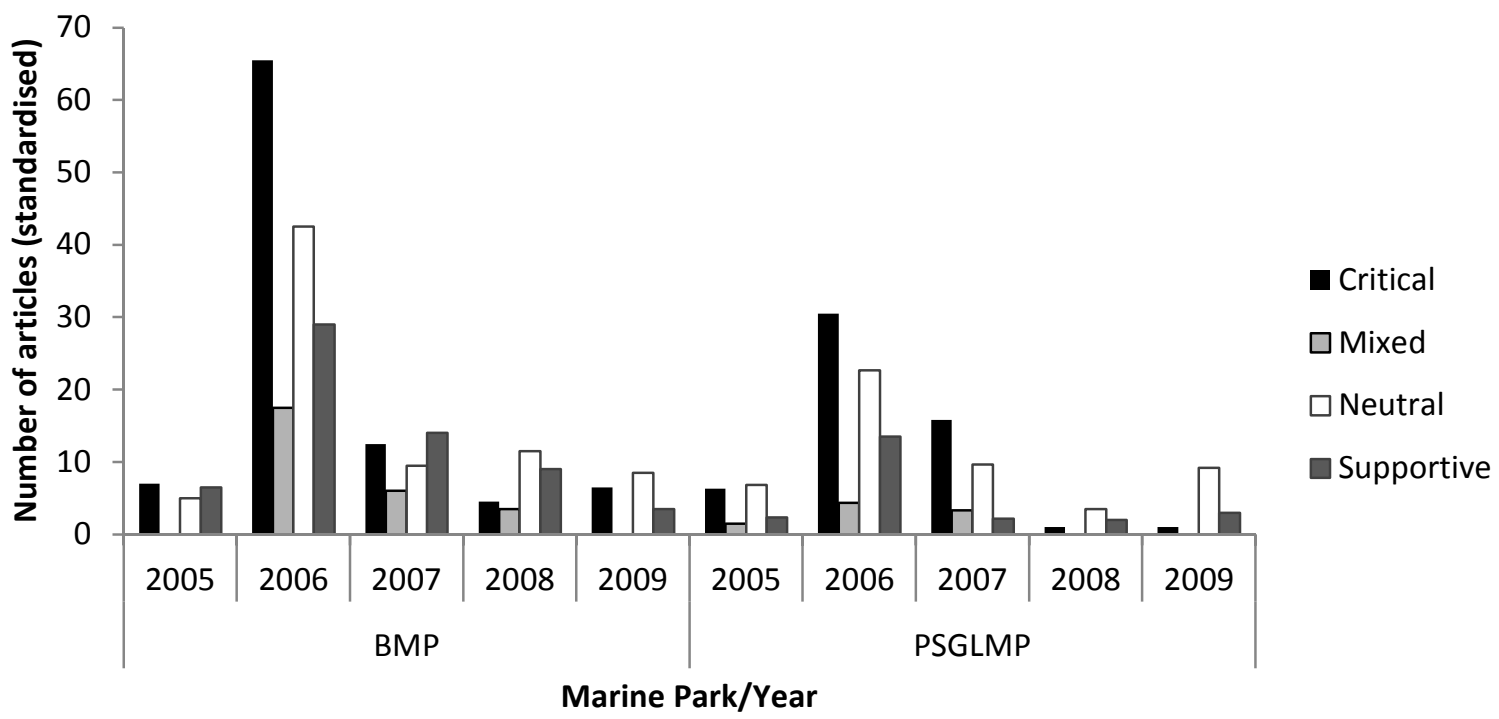

Figure 1. News articles on the marine park issue in local print media 2005-2010

In total the BMP papers had significantly more articles relating to the issue than the PSGLMP papers $(\mathrm{p}<0.001)$. There were no significant differences, however, between the proportions of the coverage which were categorised as critical, mixed, neutral or supportive across the two parks (Table 3). That is, neither park received significantly greater critical coverage than the other.

Table 3. Summary of actual and expected numbers of newspaper articles, and the distribution of attitudes towards the PSGLMP and BMP in these articles. Also shown are the results of Chi square tests comparing the frequency of different types of articles in the two marine parks for 2005-2010.

\begin{tabular}{|c|c|c|c|c|c|c|c|c|}
\hline & \multicolumn{2}{|c|}{ Critical } & \multicolumn{2}{|c|}{ Mixed } & \multicolumn{2}{|c|}{ Neutral } & \multicolumn{2}{|c|}{ Supportive } \\
\hline & Actual & Expected* & Actual & Expected & Actual & Expected & Actual & Expected \\
\hline PSGLMP & 54.6 & 52 & 9.2 & 13 & 51.8 & 45 & 23 & 29 \\
\hline BMP & 96 & 99 & 27 & 24 & 77 & 84 & 62 & 56 \\
\hline Total & 151 & 151 & 36 & 36 & 129 & 129 & 85 & 85 \\
\hline $\mathrm{Chi}^{2}$ & \multicolumn{2}{|c|}{0.135} & \multicolumn{2}{|c|}{1.582} & \multicolumn{2}{|c|}{1.599} & \multicolumn{2}{|c|}{2.356} \\
\hline$P$ value & \multicolumn{2}{|c|}{0.7137} & \multicolumn{2}{|c|}{0.2084} & \multicolumn{2}{|c|}{0.2061} & \multicolumn{2}{|c|}{0.1248} \\
\hline
\end{tabular}

*Expected vales 35\% PSGLMP, 65\% BMP

Coverage of the marine park issue was heavily dominated by one publication, the Narooma News, in the BMP area (Figure 2). While this paper had the lowest circulation and readership of all the papers studied it had disproportionate coverage of the marine park, particularly in the 2006 planning year. In total 196 articles, or 35\% of the total number of articles examined, were published in the Narooma News. This, however, was relatively evenly balanced between critical and neutral or supportive articles. 


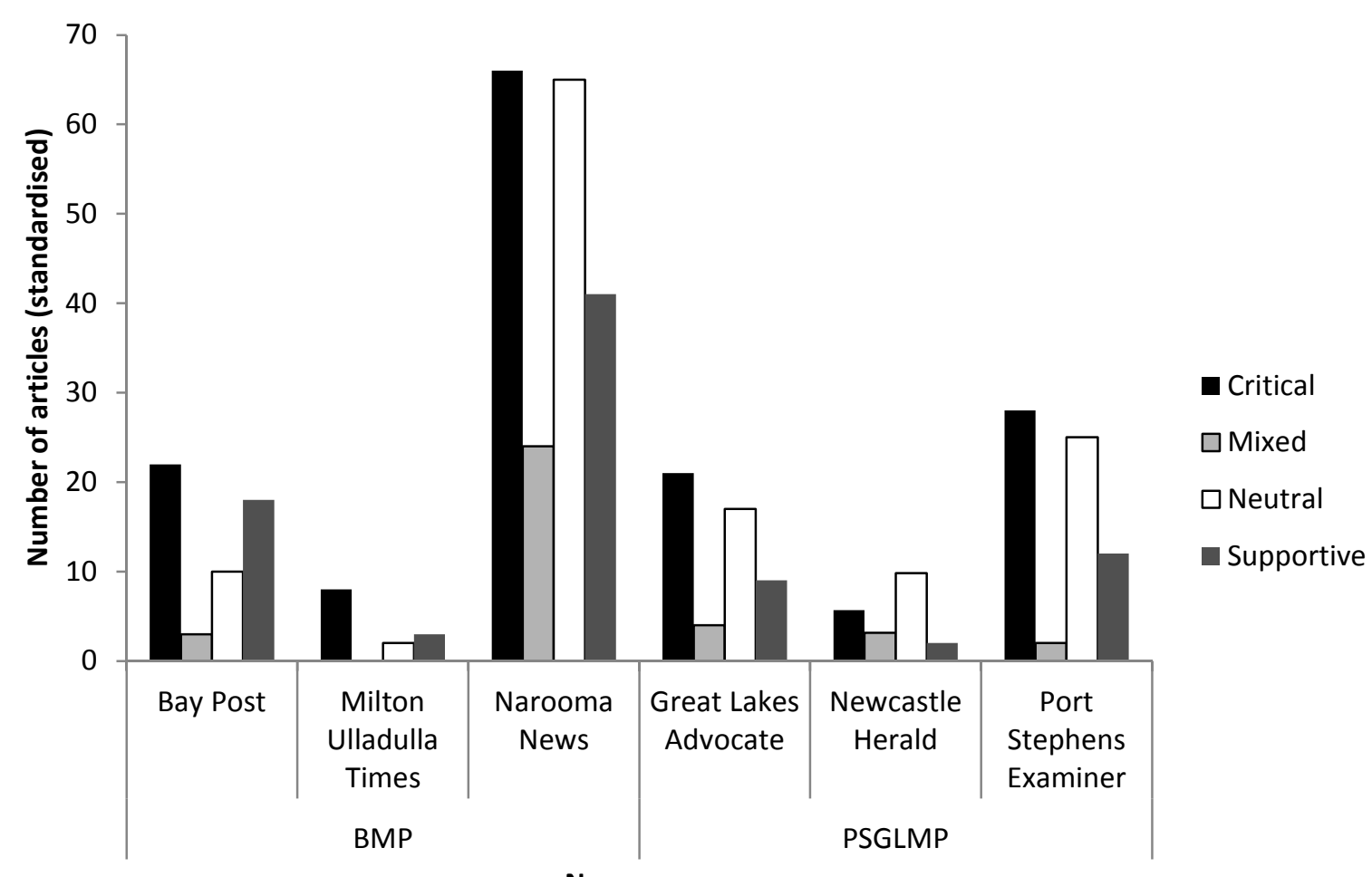

Figure 2. News articles in local print media according to source publication 2005-2010

Examination of the dominant frames in the news articles found that media framing of the issue was consistent across both park areas, with the dominant frames falling into two main categories.

\section{Why do we need the marine park?}

Media frames falling into this category primarily related to discussions over the threats versus benefits of the park. Supporters were most commonly associated with frames which sought to emphasise the tourism and fishing benefits to local communities but rarely indicated the threats the marine parks would be addressing. Critics were most commonly associated with frames which either rejected the notion that the area was threatened or highlighted a range of threats which they asserted the marine park would be ineffective at managing (which were usually defined as threats not including fishing, such as pollution or habitat loss). Finally they also highlighted threats posed by the park to the local community by identifying potential socio-economic impacts from the parks on tourism or professional fishing operations (Voyer et al., 2013a).

\section{Will a marine park work?}

Media frames relating to this category took several forms and were largely found in critical articles. They questioned the science behind the marine park, the effectiveness of the marine park in improving fish stocks, and criticised the government processes. Many opponents also made links between the declaration of the marine park and the state election, stating they believed the parks were nothing but an election sweetener to attract Green votes in metropolitan areas (For a more comprehensive examination of these media frames see Voyer et al., 2013a). 


\subsection{Letters to the editor}

A total of 465 (352 standardised) letters to the editor were examined. Letters to the editor were heavily dominated by critical letters in the early stages of the planning and implementation of the parks. A marked contrast exists here between the two parks with the BMP papers publishing large numbers of letters, and particularly critical letters, throughout the study period, whereas the PSGLMP papers had much lower numbers of letters after 2006 (Figure 3). Again the Narooma News published far greater numbers of letters to the editor than the other publications, making up $57 \%$ of the total number of letters across both parks.

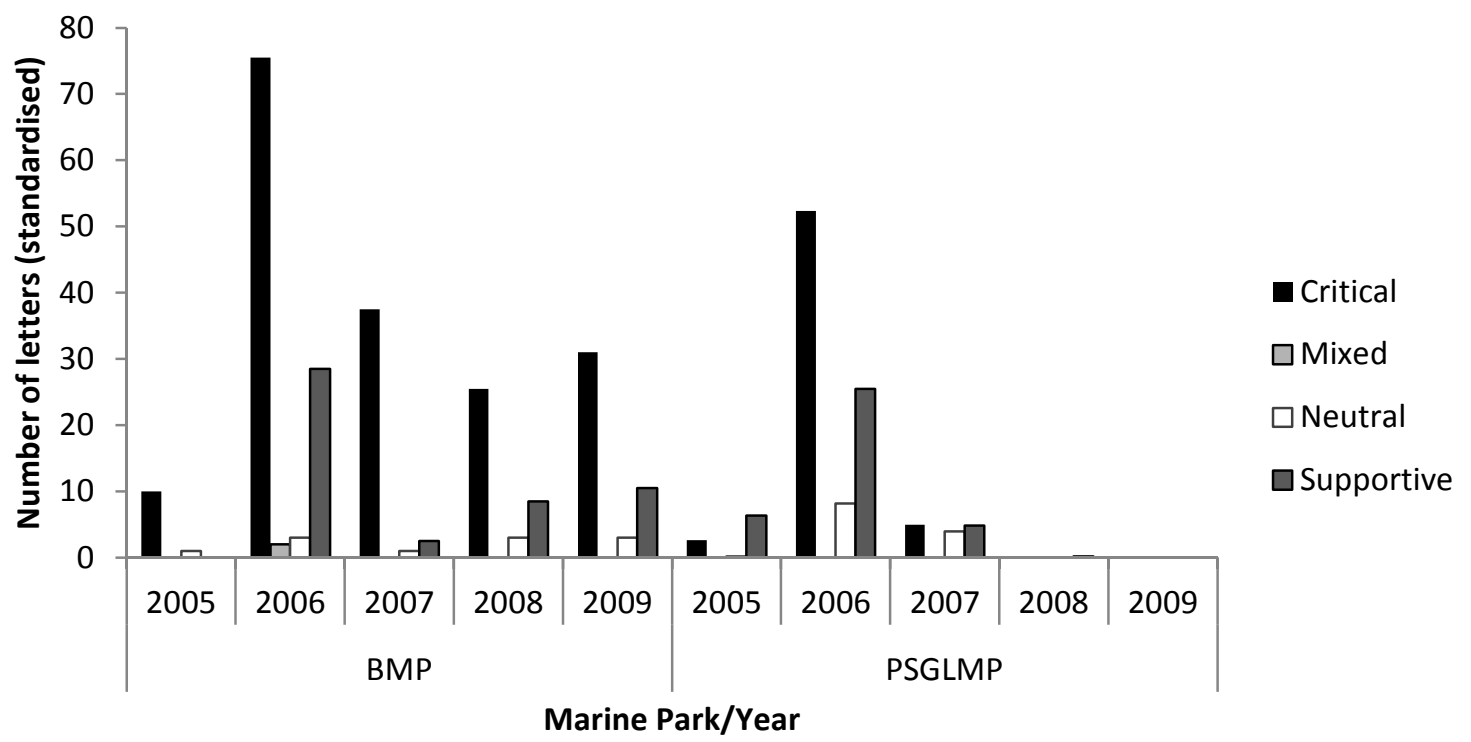

Figure 3. Letters to the editor on the marine park issue in local print media 2005-2010

Table 4 demonstrates that on average letter writers in the BMP accounted for more letters per head than in the PSGLMP, with the Narooma News showing the highest proportion of letters per writer. In fact in the Narooma News two writers accounted for 61 of the 201 letters published between 2005 and 2010. This accounts for $30 \%$ of the letters to that paper, a number not matched in any of the other papers, even by the same writers.

Table 4. Number of writers responsible for letters to the editor according to source publication - non standardised (2005-2010)

\begin{tabular}{|l|l|l|l|l|l|}
\hline Marine Park & Newspaper & $\begin{array}{l}\text { Number of } \\
\text { letters }\end{array}$ & $\begin{array}{l}\text { Number of } \\
\text { writers }\end{array}$ & Letters/writer & Average/Park \\
\hline \multirow{2}{*}{ BMP } & Bay Post & 83 & 46 & 1.8 & \multirow{2}{*}{2.24} \\
\cline { 2 - 5 } & Narooma News & 201 & 75 & 2.68 & \multirow{2}{*}{1.5} \\
\hline \multirow{3}{*}{ PSGLMP } & Great Lakes Advocate & 25 & 16 & 1.56 & 1.46 \\
\cline { 2 - 5 } & Newcastle Herald & 86 & 59 & 1.49 & \\
\cline { 2 - 5 } & Port Stephens Examiner & 70 & 47 & & \\
& & & &
\end{tabular}




\subsection{News media sources}

The role of the primary definer in each news article was classified according to stakeholder group. The most prominent primary definers were politicians and government officials (Figure 4).

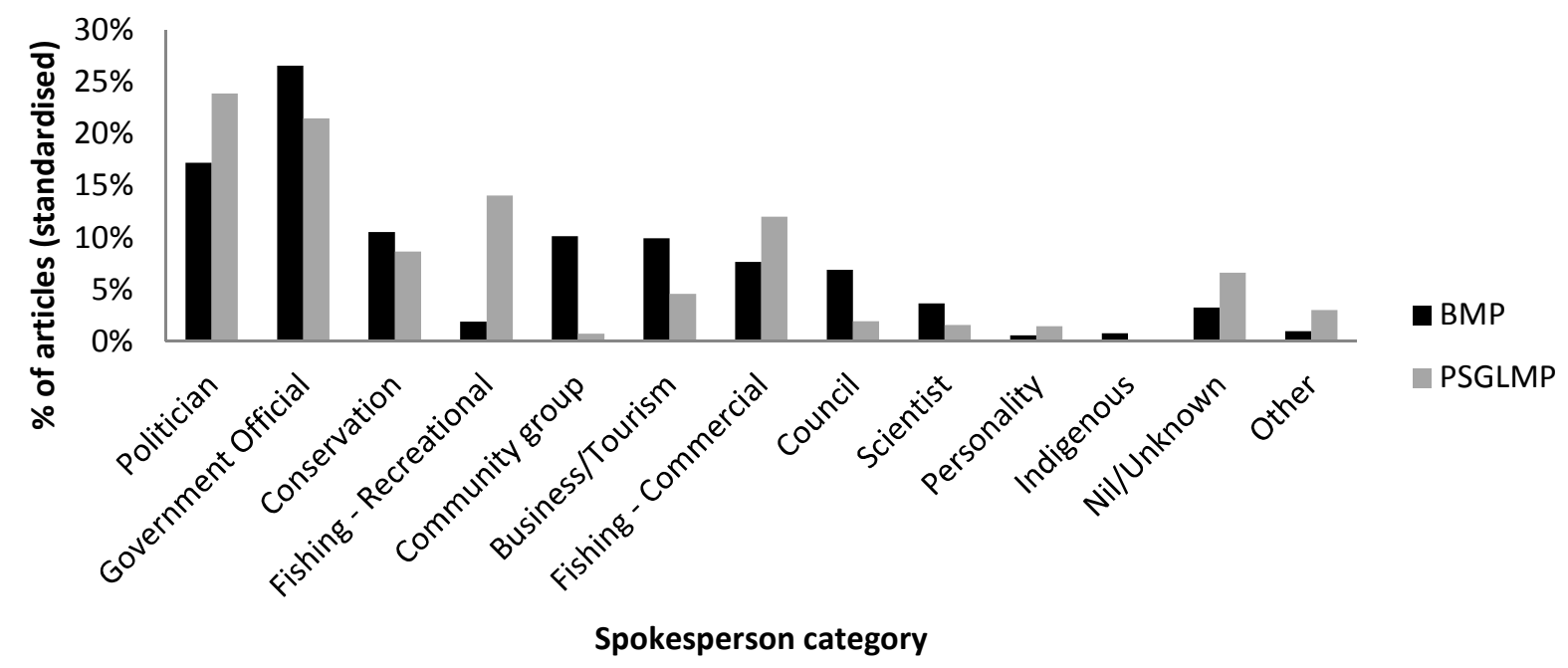

Figure 4. Representation of major stakeholder groups as primary definer in marine park news (expressed as percentage of total articles for each park)

In the case of government officials the majority of the articles (66\% in the PSGLMP and 68\% in the BMP) were neutral, often related to process, such as when meetings were being conducted, or when submissions were due. In the case of politicians the tone of the article was largely determined by the political persuasion of the politician featured (Figure 5). In the BMP the local Member of Parliament at the time was a member of the then (conservative) opposition party. He made up the bulk of the critical articles in which a politician was the primary definer in the BMP. Government politicians in the BMP were most likely to be associated with supportive arguments. Representatives of the then Labor Government were usually the Minister for the Environment or the Minister for Fisheries, who were jointly responsible for the implementation of the park. The local election candidate for the Labor party was virtually absent from the media coverage of this debate. 


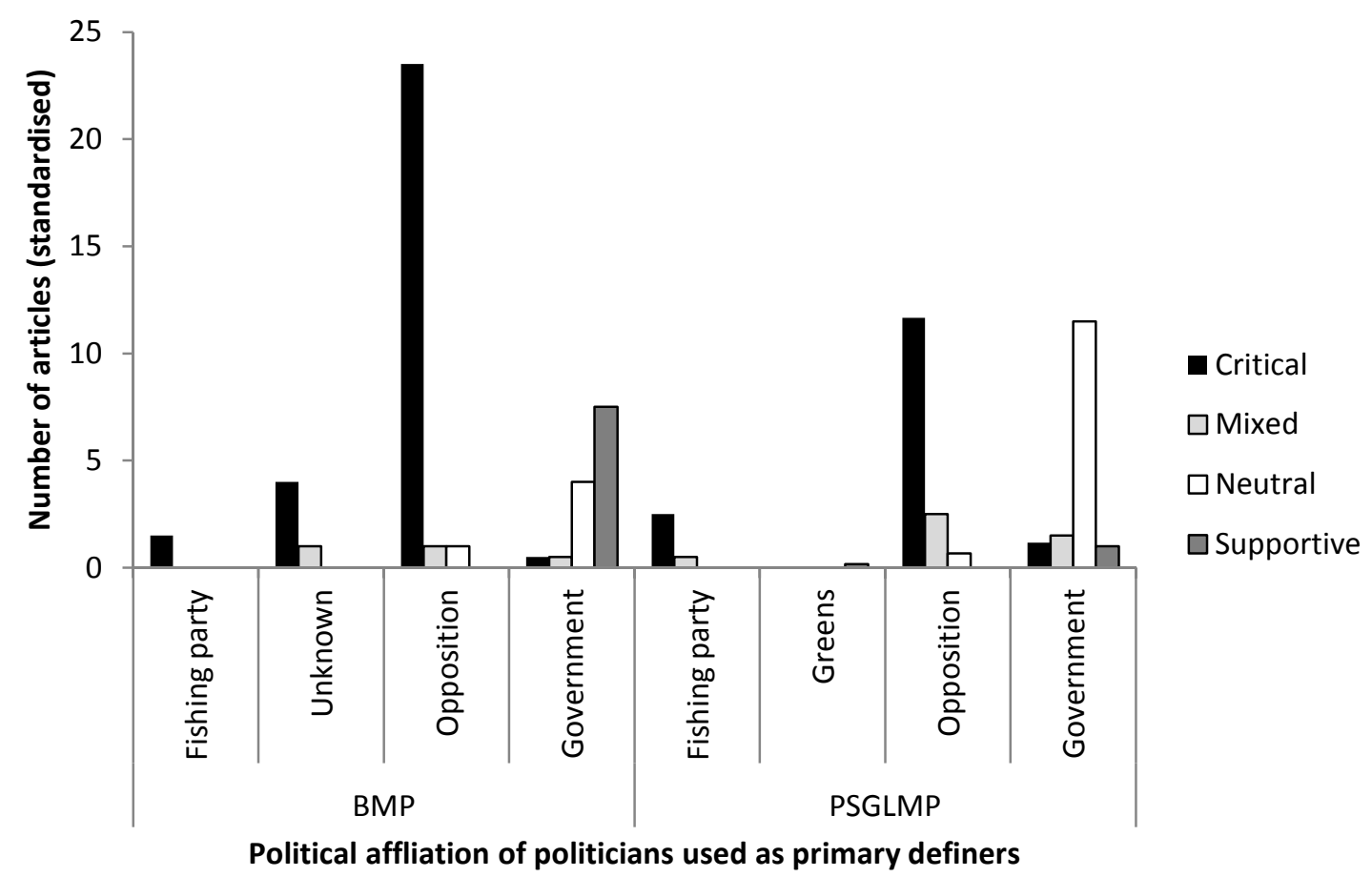

Figure 5. Affiliations of politicians used as primary definers and the frequency distribution of the articles in which they featured which were classified as critical, supportive, mixed or neutral. NB The 'fishing party' category is an amalgam of three fishing, hunting or outdoor recreation parties active at the time.

In the PSGLMP, the then Labor Government was far more likely to be associated with neutral, rather than supportive articles (Figure 5). Government politicians quoted included the relevant ministers, the premier and local Labor party election candidates from the two electorates that included the park. Similarly a range of politicians from different conservative parties were also used as sources in the PSGLMP, including a number of minor parties running on platforms relating to fishing and hunting.

These results suggest a much clearer political demarcation of the dispute in the BMP along party lines with the then Labor Government cast as the supporters and the opposition, and particularly the local Member of Parliament, cast as the opponents. In the PSGLMP Government politicians and officials had a role in the media relating largely to process rather than a positive message about the marine parks. This left supportive articles primarily in the domain of conservation groups.

In both parks conservation groups were the groups most associated with supportive articles, being responsible for $41 \%$ of supportive articles in the PSGLMP and 35\% in the BMP. There were a wide variety of spokespeople used in the PSGLMP, predominately from one of three major environmental Non-Government Organisations (e-NGOS). They ran significant, funded campaigns in both parks, and in some cases used paid campaigners. In the BMP the majority of the conservation sources identified as primary definers were from one of three local, grass roots organisations run by volunteers (Voyer et al., 2013a).

Critical coverage in the BMP was largely dominated by two individuals from local groups that were aligned with recreational fishing interests but also claimed to represent a broader constituency of commercial fishers, business owners and the general public (classified as community groups in Figure 4). In the PSGLMP spokespeople came from a wider range of sources, including several local branches of a state-wide recreational fishing lobby group, unaligned recreational and commercial fishers and bait and tackle shop owners (Voyer et al., 2013a). 


\subsubsection{Motivations and aspirations of media sources}

In total five recreational fishers (three in the BMP and two in the PSGLMP) and four conservationists (three in the BMP and one in the PSGLMP) were specifically interviewed in relation to their roles in the media. All the five fishing spokespeople interviewed were extremely active and engaged fishers, with fishing playing a dominant role in their lives. Of the five fishing spokespeople interviewed two, arguably the most active in the media in each park, had been motivated to get involved in the campaign against the marine park by a wider sense of disillusionment or anger over the growth in influence and power of The Greens political party and associated conservation movement.

I hate the Greens, I hate them with a passion. By holding the Government of the day, at various levels, to ransom .. I think they have led this country into many errors of judgement and are making this country soft.

BMP fisher

You only have to look at the bills the Greens put through parliament, $90 \%$ of all the stuff they do is gay marriage, gay adoption, drug legalisation, all kinds of stuff that is completely irrelevant to conservation but I don't see them out in the public telling people that. They have done that by stealth.

PSGLMP fisher

All but one of the fishing spokespeople interviewed were fundamentally opposed to their local marine park, or more specifically to the Sanctuary Zone or no take components of the park. Most had strongly opposed the park from the outset and had maintained their opposition over time, continuing their lobbying efforts to reverse the zoning plans or institute a review of the plans. The exception was one fisher from the PSGLMP. While he remained sceptical about all of the claims about the potential benefits of the marine park he had remained engaged in the planning process and felt the marine park had struck a reasonable balance which he hoped would prove beneficial in the long run.

I don't know if it's going to be successful, I'm assuming that it will be and I'm not relying on any science whatsoever because it's so contradictory and it basically supports whoever's philosophy.

PSGLMP fisher

For all of the four conservation spokespeople the marine park issue was one of a variety of conservation endeavours in which they were engaged. They had active roles in previous and current anti-forestry campaigns, and lobbying relating to coastal development, mining and industry. All four conservation spokespeople expressed a desire to 'protect' the marine environment and strongly supported MPAs, and in particular Sanctuary Zones, as one of the best means of achieving this.

(it seemed) crazy... that there was no formal protection for the sea, it just seemed obvious to me that there needed to be something.

\section{PSGLMP conservationist}

\subsubsection{Politics and ideology}

A key theme that emerged in the interview data was the importance of politics and ideology in the debate over the marine park. All five fishing spokespeople and two of the conservation spokespeople indicated that they were very politically aware and active in political circles, and were often engaged in direct lobbying of politicians or other political campaigns (Table 5). Often they felt like they had established media networks which provided them with some power in the debate. 
Table 5: Count of references made to key political themes within interviews with conservation and fishing media spokespeople in the Port Stephens-Great Lakes Marine Park (PSGLMP) and the Batemans Marine Park (BMP).

\begin{tabular}{|c|c|c|c|c|}
\hline \multirow[t]{2}{*}{ Theme } & \multirow[t]{2}{*}{ Spokes-person } & \multicolumn{2}{|c|}{$\begin{array}{l}\text { Count of coding } \\
\text { references }\end{array}$} & \multirow[t]{2}{*}{ Example quote } \\
\hline & & PSGLMP & BMP & \\
\hline \multirow{2}{*}{$\begin{array}{l}\text { Politically active: } \\
\text { discussion about } \\
\text { lobbying efforts and } \\
\text { involvement in } \\
\text { direct political } \\
\text { action }\end{array}$} & Conservation & 1 & 9 & $\begin{array}{l}. . \text { we had been battling..to get commercial fishing } \\
\text { out of the Lake and ..the declaration of the } \\
\text { Batemans Marine Park was the platform for that to } \\
\text { happen.. }\end{array}$ \\
\hline & Fishing & 7 & 13 & $\begin{array}{l}\text { That's the only thing that frightens them (the } \\
\text { bureaucrats) is the press. }\end{array}$ \\
\hline \multirow{2}{*}{$\begin{array}{l}\text { Politically aware: } \\
\text { general discussion } \\
\text { of the political } \\
\text { environment in } \\
\text { which the parks } \\
\text { were declared/ } \\
\text { planned }\end{array}$} & Conservation & 0 & 23 & $\begin{array}{l}\text { I think Labor people see the Greens as taking their } \\
\text { constituents away... there's a lot of resentment } \\
\text { there about that but the Labor Party can only } \\
\text { blame itself because it neglected that agenda, it's } \\
\text { not a Green party by any means }\end{array}$ \\
\hline & Fishing & 13 & 4 & $\begin{array}{l}\text { This was a Labor seat and after the marine park } \\
\text { was declared it has been a Liberal seat ever since. } \\
\text { Certainly enough people were unhappy about it to } \\
\text { vote Liberal. }\end{array}$ \\
\hline
\end{tabular}

\subsubsection{Who cares wins and the BMP}

In the course of the interviews in the BMP it was clear that both 'sides' saw the marine park as a battle in which there were winners and losers. Each sought to position themselves as winners fighting for a just cause and to establish their environmental credentials, highlighting that they cared about the environment more than their opponents.

I've lost areas, one of my favourite areas I can't go riding in, it's been declared wilderness - I miss cycling in the wilderness area but...it's for the greater good, we compromise a little bit in looking after our environment.

\section{BMP conservationist}

The biggest seagrass bed here is still not covered its open for people to go in and destroy it, but...we want that area locked off because it is a precious area, and these lunatics that put the park in place still don't even know where it is.

\section{BMP fisher}

Both sides also sought to establish themselves as caring for their communities. The conservation spokespeople highlighted the tourism and fishing benefits of the park to the local community and held firm opinions that the park had been beneficial for the area.

For very many reasons the marine park was a huge win for residents here as well as visitors to this shire, I have collected every fishing report for the last 6 years (and) the fishing is just so good.

\section{BMP conservationist}

All of the three BMP fishing spokespeople, on the other hand, talked at length about the harm they believed the park had done to their local communities.

Within 12-18 months since the marine park started we've had 27 businesses close down.

\section{BMP fisher}


Table 6 includes some examples of the adversarial way in which the debate was conducted in the BMP. In particular the language around the BMP indicates how polarised the debate has become and how the media was often seen by the key combatants as a battleground. Interview participants talked of fiery confrontations, damage to property, and intimidating behaviour as evidence of the animosity which this debate inspired, all of which was played out in the media.

Table 6: Count of references made to key 'battleground' themes within interviews with conservation and fishing media spokespeople in the BMP

\begin{tabular}{|c|c|c|c|}
\hline Theme & Spokesperson & $\begin{array}{l}\text { Count of } \\
\text { coding } \\
\text { references }\end{array}$ & Example quote \\
\hline \multirow{2}{*}{$\begin{array}{l}\text { The marine park } \\
\text { debate as a battle: } \\
\text { use of battle } \\
\text { language }\end{array}$} & Conservation & 12 & $\begin{array}{l}\text { they've been very persistent, but that's fine the } \\
\text { conservation movement is persistent too and it's just a } \\
\text { matter of who is going to outlast who. }\end{array}$ \\
\hline & Fishing & 3 & I study the opposition very carefully. \\
\hline \multirow{2}{*}{$\begin{array}{l}\text { Local media the } \\
\text { battleground: } \\
\text { reference to local } \\
\text { media being the } \\
\text { medium on which } \\
\text { the battle was } \\
\text { fought }\end{array}$} & Conservation & 3 & $\begin{array}{l}\text { Certainly the ringleader..was very sensitive to media, that } \\
\text { was his Achilles heel }\end{array}$ \\
\hline & Fishing & 10 & $\begin{array}{l}\text { When I have my attacks on him published in the paper I can } \\
\text { walk to work and people stop me and say to me 'get into } \\
\text { him', because they hate marine parks..I can.. have 15-20 } \\
\text { people come up and say 'very good letter'. }\end{array}$ \\
\hline
\end{tabular}

\subsubsection{Who speaks for who and the PSGLMP}

While there were strong feelings about the marine park amongst the PSGLMP spokespeople the battleground terminology did not emerge as a major theme in the interview data to the same extent as in the BMP. Instead there was a greater emphasis on whose voice represented the majority view and therefore who should be listened to the most. One of the fishers felt strongly that the majority of marine park opponents in his community were driven by ideology rather than fact. He felt he represented the majority of fishers in his more moderate views:

only between 2 and $4 \%$ of rec fishers in this state are members of clubs, so 96\% of fishers are just fun loving, who like to dangle a line and take their kids and they deserve consideration as much as the so called experts, they are a silent massive majority but it's the $4 \%$ that make all the noise.

PSGLMP fisher

The price for this moderate opinion appeared to be rejection of the legitimacy of his voice from other fishers in the area who provided an alternative point of view on the marine park. This included another prominent fishing spokesperson for the PSGLMP who also believed he spoke for the majority of recreational fishers. He represented these fishers as environmentally friendly with an intimate knowledge of their local marine waters. This meant they were best placed to understand the needs of the marine environment.

We love our waterway, we're not going to damage our waterway. We pick up rubbish...we're out there in the environment. I talk to these marine biologists from the Greens and they don't even go out to sea, half of them haven't even been on a boat. How can you be a marine biologist and be telling us how it is and you haven't even been out in the environment, it's just crazy.

PSGLMP Fisher 
Finally, the conservation spokesperson interviewed felt she spoke for the majority of the wider community who she believed were in favour of the marine park.

We did commission a public opinion report...and that was great because it did give us a bit of mandate behind what we were doing... it pretty much overwhelming said that people did want protection for the sea.

\section{PSGLMP conservationist}

\subsubsection{The role of the media in campaign strategies}

While the conservation and fishing groups in both parks acknowledged the importance and power of the media each sought to make use of their media exposure in different ways. The fishing spokespeople saw the media as a powerful lobbying tool which they continued to employ to harness support for their cause and build pressure on local politicians and the Government. In the BMP the letters to the editor page of the Narooma News was a key battleground for their dispute with conservationists, as well as an important campaign tool used to keep the issue in the public eye. This deeply personal, adversarial and ongoing debate in the letters pages from a handful of key protagonists was unique to the BMP, and more specifically the Narooma News. It has an editorial policy of publishing almost every letter they receive (Editor Narooma News pers comm).

We've let it die down the last 6 months...but now it's all ignited again because (a conservationist) started something a few weeks ago, made a bit of an attack, so last week's paper everyone attacked him.

\section{BMP fisher}

Conservation groups in both parks also made use of the letters to the editor pages during the planning process, including through co-ordinated letter writing campaigns. However, since the finalisation of the zoning plans the conservation spokespeople have largely disengaged from the media as a lobbying tool, preferring to use it in a neutral, educative way. This strategy attempts to reframe the debate around marine parks and to educate and inform the wider population about the importance of marine parks and marine wildlife.

We've been concentrating on getting through to school groups and things and also fortnightly columns in the paper about marine animals.

\section{BMP conservationist}

\section{Discussion}

\subsection{Media bias and the PSGLMP and BMP}

The results of this study indicate that media bias was not a factor in the differential community reactions to the PSGLMP and BMP. While critical coverage dominated in both parks in the planning year it was generally balanced with neutral and supportive articles over the study period and no park received significantly greater critical coverage than the other. In addition relatively equal coverage was given to major stakeholder groups, especially recreational fishers and the conservation groups, although notably, the voices of local Indigenous communities and scientists were largely absent from the media in both communities. Key differences between the parks begin to emerge, however, when unpacking the role of politics and ideology in the coverage of each park.

Politics and ideology played a significant role in the media coverage of the BMP, particularly in the planning (and pre-election) year of 2006. The media covered the debate in a manner that emphasised 
the adversarial nature of politics - the local Member of Parliament was cast in the role of the defender of the local community against the Sydney based Government politicians. Therefore the debate was framed in the local media not only as an 'left vs right' ideological battle, but as one of a local community versus 'outsiders'. In addition the use of sources was heavily focused on a handful of individuals with strong political and ideological convictions, who were firm in their positions of support for or opposition to the park. As one of the key protagonists acknowledged:

In essence it's like religion. Not everyone that believes in religion goes to church or goes around bashing bibles. However on this issue I am a bible basher at one extreme, as the conservationists are bible basher's at the other end of the spectrum. We each represent probably about 10\% of the community, probably $75 \%$ of the community don't give a damn, the rest probably disagree or agree to varying levels. As $25 \%$ of the population are recreational fishers, undoubtedly there are more people who disagree with Marine Parks in their current format.

BMP fisher

The key protagonists in the BMP debate were all driven by a passionate conviction that their actions were in the best interests of their local marine environment and/or their local communities. They professed to care about the local marine environment but defined caring in different ways based on differing representations of the threats to the marine environment and the most appropriate responses to these threats. Acknowledging that these positions of support or opposition were likely to have been influenced by their ideological convictions does not imply their voices were not of value in the debate. The prominence of these spokespeople in the BMP media may have engaged the community in discussions immediately relevant to the success of the park, such as the social impacts of the parks and the value and role of MPAs in marine conservation. The dominance of their voices, however, is also likely to have meant that the concerns and ideas of other community members may not have been heard.

In the PSGLMP media sources were more diverse and, while ideological and political divisions were clearly evident, this greater diversity of sources appears to have allowed for a more nuanced coverage of the issue. While it is clear that the park was still seen as a deeply political issue in the PSGLMP, this may have been neutralised to some extent by the way Government politicians were framed. Unlike the BMP, the messages of politicians in the PSGLMP local newspapers were concerned with questions of policy and process rather than with defence of the concept of the marine park itself. In addition, one of the more prominent fishing spokespeople maintained a neutral position in relation to the park, rather than the blanket opposition expressed by other fishing media sources.

The results of this research, therefore, suggest that the media debate over the marine parks was aligned with ideology to a much greater extent in the BMP than the PSGLMP. It is not possible to determine whether this drove the intensely polarised debate in the BMP or whether the media was simply reflecting what was already an ideological battle. The reality was probably a combination of both. The BMP area has a long history of environmental conflict, with relatively recent clashes between conservationists and forestry workers referenced in some interviews (see McManus, 2002 for details of forestry conflicts). Therefore existing ideological tensions are likely to have influenced community responses to the park. In addition, the declaration of the park in the lead up to a state election would also have encouraged politicisation of the issue along party lines and this may in turn have been influential in community responses in the traditionally conservative BMP electorate. Further insight may be provided by comparative research across a broader range of media outlets to determine whether this trend towards more polarised coverage was consistent across all reporting of the BMP or limited to local newspapers, and more specifically the Narooma News. 


\subsection{Politics, MPAs and the media}

The PSGLMP and BMP case studies used in this research reflect the tendency in media framing to align the conservation movement with the progressive end of the political spectrum and resistance to environmental interventions with more conservative political persuasions (Lakoff, 2010). The underlying political dimension to the debate translated into highly adversarial and polarised media coverage, particularly in the BMP, reducing the coverage of complex marine conservation management and resource allocation decisions into a simplified 'left vs right' political conflict. This is perhaps an unavoidable consequence of a 'top down' MPA declaration in an adversarial democratic system whereby the environment becomes another key battle ground over which political enemies fight. The danger of the environment being seen as the exclusive domain of the 'left' of politics, however, is that it potentially alienates a large section of the community who may have concerns and ideas about environmental management but do not necessarily align themselves ideologically with the left. Equally, constituents who have concerns about the effectiveness of the proposed conservation strategies or the process of their implementation may also feel disenfranchised if they do not wish to align themselves with the 'right' of the political spectrum or be labelled as 'anti-conservation'. Therefore media coverage which reports 'both' sides of the story in this highly simplified manner may in fact undermine participatory democracy by handing power to a small number of spokespeople with undeclared motives for their involvement. It can also undermine attempts to build consensus by allowing each side to dismiss the others views as 'extreme' without the need to consider and address their fundamental concerns.

Lakoff (2010) suggests that, in reality, a large section of the community have mixed value systems, being 'conservative' on some issues and 'progressive' on others. This creates fertile ground for political enemies to engage in ideological warfare in an attempt to win over the 'middle', as seen in the BMP, but it may also provide opportunity for pragmatism and compromise by seeking out and capitalising on shared values and belief systems. This research demonstrated that even the most galvanised marine park opponents shared with the supporters a deep passion for their local marine waters and a variety of ideas about how it should be cared for. How to extend this local passion to a broader sense of global citizenship and an awareness of the role of local level MPAs in the global response to large scale environmental crises is a challenge worthy of further research attention.

From a policy perspective, this research indicates that a top down approach brings with it inherent politicisation which is exacerbated by media preferences for stories which involve conflict and political tensions. Incorporation of 'bottom up' approaches, which explore the nature of people's concerns and their aspirations for the future of their local marine environment, may help to identify common ground, potential trade-offs and 'non-negotiables', laying the foundations for the development of MPAs built on consensus rather than conflict and allowing local communities to feel that they have more ownership of their MPA. There is increasing recognition around the world, including NSW, of the potential of marine spatial planning to assist in integrating MPAs with community objectives (Gleason et al., 2010, Agardy et al., 2011, Beeton et al., 2012, Fox et al., 2013).

The PSGLMP example demonstrates that planning processes may deflect some of the hostilities evidenced in the BMP if a diversity of sources is used and moderate voices are accommodated in the associated media. MPA planning processes may therefore be able to circumvent polarised reporting of stakeholder issues by seeking out and promoting a range of perspectives and opinions. This does not mean the voices of stakeholders such as those interviewed in this study should be suppressed or sidelined. Passionate advocates such as these can play an important role in consultation processes and the democratic process by stimulating discussion and challenging existing paradigms. However, the dominance of a handful of voices can also discourage participation in the debate by other members of 
the community (Wahl-Jorgensen, 2006). A variety of voices and perspectives, both across stakeholder groups and within them, is therefore required in order to seek middle ground, and build community consensus.

\section{Conclusions}

The power of local media is often overlooked in research into community responses to environmental management interventions. The global imperative for improved marine conservation management is unlikely to translate into effective local level action without the support of communities and local media is a key means of influencing and reflecting the attitudes of these communities. The journalistic traditions of balance and objectivity often translate to simplistic coverage of issues that are adversarial or contested. This does little to aid a democratic and inclusive debate, tending instead to favour elite, articulate and impassioned members of the community. These privileged spokespeople fight to win the hearts and minds of the majority by invoking their ideology and values which can promote difference rather than seek middle ground. Recognising that ideology and politics is an inevitable component of modern environmental debates, however, does not imply that it should be accepted without challenge. Efforts should be made to understand and acknowledge the role of ideology in order to avoid undue influence on planning exercises.

\section{References}

Agardy, T., P. Bridgewater, M. P. Crosby, J. Day, P. K. Dayton, R. Kenchington, D. Laffoley, P. McConney, P. A. Murray, J. E. Parks, and L. Peau. 2003. Dangerous targets? Unresolved issues and ideological clashes around marine protected areas. Aquatic Conservation: Marine and Freshwater Ecosystems 13:353-367.

Agardy, T., G. N. di Sciara, and P. Christie. 2011. Mind the gap: Addressing the shortcomings of marine protected areas through large scale marine spatial planning. Marine Policy 35:226232.

Banks, S. A. and G. A. Skilleter. 2010. Implementing marine reserve networks: A comparison of approaches in New South Wales (Australia) and New Zealand. Marine Policy 34:197-207.

Baysha, O. and A. Calabrese. 2012. The Global in the Local: A Case Study on Deforestation in a Ukrainian Journalistic Field. Environmental Communication: A Journal of Nature and Culture 6:156-174.

Beeton, R., C. Buxton, G. Cutbush, P. Fairweather, E. Johnston, and R. Ryan. 2012. Report of the Independent Scientific Audit of Marine Parks in New South Wales. http://www.marineparksaudit.nsw.gov.au/audit-report/ Accessed: 23/03/2013

Boissonneault, M., W. Gladstone, P. Scott, and N. Cushing. 2005. Public perception of the behaviour of the grey nurse shark. Electronic Green Journal 22:1-15.

Boykoff, M. T. and J. M. Boykoff. 2004. Balance as bias: global warming and the US prestige press. Global Environmental Change 14:125-136.

Carneiro, G. 2011. Marine management for human development: A review of two decades of scholarly evidence. Marine Policy 35:351-362.

Compas, E., B. Clarke, C. Cutler, and K. Daish. 2007. Murky waters: Media reporting of marine protected areas in South Australia. Marine Policy 31:691-697.

Cottle, S. 2000. Rethinking news access. Journalism Studies 1:427-448.

Cottle, S. 2011. Taking global crises in the news seriously: Notes from the dark side of globalization. Global Media and Communication 7:77-95.

Creswell, J. W. 2009. Research Design: Qualitative, Quantitative and Mixed Methods Approaches. Sage Publications Inc, California.

Dikou, A. and N. Dionysopoulou. 2011. Communicating a Marine Protected Area Through the Local Press: The Case of the National Marine Park of Alonissos, Northern Sporades, Greece. Environmental Management 47:777-788. 
Entman, R. M. 1993. Framing: Toward Clarification of a Fractured Paradigm. Journal of Communication 43:51-58.

Entman, R. M. 2004. Projections of power: framing news, public opinion, and U.S. foreign policy. The University of Chicago Press, Chicago.

Ericson, R. V., P. M. Baranek, and J. B. L. Chan. 1989. Negotiating control : a study of news sources. University of Toronto Press, Toronto.

Fiske, S. J. 1992. Sociocultural aspects of establishing marine protected areas. Ocean \& Coastal Management 17:25-46.

Fox, E., S. Hastings, M. Miller-Henson, D. Monie, J. Ugoretz, A. Frimodig, C. Shuman, B. Owens, R. Garwood, D. Connor, P. Serpa, and M. Gleason. 2013. Addressing policy issues in a stakeholder-based and science-driven marine protected area network planning process. Ocean \& Coastal Management 74:34-44.

Gitlin, T. 1980. The whole world is watching: mass media in the making and unmaking of the New Left. University of Calfornia Press, Berkeley.

Gleason, M., S. McCreary, M. Miller-Henson, J. Ugoretz, E. Fox, M. Merrifield, W. McClintock, P. Serpa, and K. Hoffman. 2010. Science-based and stakeholder-driven marine protected area network planning: A successful case study from north central California. Ocean \& Coastal Management 53:52-68.

Gorton. 2013. Batemans Marine Park fishing restrictions lifted. Narooma News. Fairfax Media, Narooma. http://www.naroomanewsonline.com.au/story/1361393/batemans-marine-parkfishing-restrictions-lifted/ Accessed 13/03/2013

Hall, S., C. Critcher, T. Jefferson, J. Clarke, and B. Roberts. 1978. Policing the Crisis; Mugging, the State, and Law and Order. The Macmillan Press Ltd, London.

Hodgkinson, K. and R. Parker. 2011. Media release:NSW Government takes the politics out of marine parks. Minister for Primary Industries, Minister for Small Business, and the Minister for the Environment, Minister for Heritage. Parliament of NSW, Sydney. http://www.mpa.nsw.gov.au/pdf/mr-25-05-11.pdf Accessed: 25/05/2011

Lakoff, G. 2010. Why it Matters How We Frame the Environment. Environmental Communication: A Journal of Nature and Culture 4:70-81.

Lester, L. 2010. Media and Environment. Polity Press, Cambridge, UK.

Lundquist, C. J. and E. F. Granek. 2005. Strategies for Successful Marine Conservation: Integrating Socioeconomic, Political, and Scientific Factors. Conservation Biology 19:1771-1778.

Maxwell, J. A. 2005. Qualitative Research Design: An Interactive Approach. 2 edition. Sage Publications Inc., Thousand Oaks, California.

McCay, B. J. and P. J. S. Jones. 2011. Marine Protected Areas and the Governance of Marine Ecosystems and Fisheries. Conservation Biology 25:1130-1133.

McManus, P. 2002. The potential and limits of progressive neopluralism: a comparative study of forest politics in Coastal British Columbia and South East New South Wales during the 1990s. Environment and Planning A 34:845-865.

Miles, M. B. and A. M. Huberman. 1994. Qualitative data analysis : an expanded sourcebook. 2nd edition. Sage Publications, Thousand Oaks.

NSW Government. 2013. A New Approach: NSW Marine Estate. NSW Government, Sydney. http://www.dpi.nsw.gov.au/info/marinereform Accessed: 29/3/2013

Robin, L. 2012. Global ideas in local places: The humanities in environmental management. Environmental Humanities 1:69-84.

Ross, K. 2006. Open source? Hearing voices in the local press. Pages 232 - 244 in B. Franklin, editor. Local journalism and local media: making the local news. Routledge, London.

Scheufele, D. A., J. Shanahan, and S.-H. Kim. 2002. Who Cares about Local Politics? Media Influences on Local Political Involvement, Issue Awareness, and Attitude Strength. Journalism \& Mass Communication Quarterly 79:427-444.

Schlesinger, P. 1990. Rethinking the sociology of journalism: Source strategies and the limits of media-centrism. Pages 61-83 in M. Ferguson, editor. Public Communication: The New Imperiatives. Future directions for media research. Sage, London.

Spalding, M., L. Wood, C. Fitzgerald, and K. Gjerde. 2010. The 10\% Target: Where do we stand? Page 96 in C. Toropova, I. Meliane, D. Laffoley, E. Matthews, and M. Spalding, editors. 
Global Ocean Protection: Present Status and Future Possibilities. Brest, France: Agence des aires marines protegees, Gland, Switzerland, Washington, DC and New York, USA: IUCN WCPA Cambridge UK: UNEP-WC-MC, Arlington USA:TNC, Tokyo, Japan: UNU, New York USA: WCS, .

van Vuuren, K. 2009. Press Bias and Local Power in the Toowoomba Water Referendum Communication, Politics \& Culture 42:55-73.

Voyer, M., T. Dreher, W. Gladstone, and H. Goodall. 2013a. Carving the stake: dodgy science or global necessity? Local media reporting of marine parks.in S. Cottle, editor. Environmental Conflict and the Media. Peter Lang, New York.

Voyer, M., W. Gladstone, and H. Goodall. 2012. Methods of social assessment in Marine Protected Area planning: Is public participation enough? Marine Policy 36:432-439.

Voyer, M., W. Gladstone, and H. Goodall. 2013b. Understanding marine park opposition: the relationship between social impacts, environmental knowledge and motivation to fish. Aquatic Conservation: Marine and Freshwater Ecosystems.

Wahl-Jorgensen, K. 2006. Letters to the editor in local and regional newspapers: Giving voice to readers. Pages 221-231 in B. Franklin, editor. Local journalism and local media: making the local news. Routledge, London.

Ward, S. and K. van Vuuren. 2013. Belonging to the Rainbow Region: Place, Local Media, and the Construction of Civil and Moral Identities Strategic to Climate Change Adaptability. Environmental Communication: A Journal of Nature and Culture 7:63-79.

Weible, C. 2008. Caught in a Maelstrom: Implementing California marine protected areas. Coastal Management 36:350-373.

Wescott, G. 2006. The long and winding road: The development of a comprehensive, adequate and representative system of highly protected marine protected areas in Victoria, Australia. Ocean \& Coastal Management 49:905-922.

Wolch, J. R., A. Gullo, and U. Lassiter. 1997. Changing Attitudes Toward California Cougars. Society \& Animals. Journal of Human-Animal Studies 5.

Wolfenden, J., F. Cram, and B. Kirkwood. 1994. Marine Reserves in New Zealand: A Survey of Community Reactions. Ocean \& Coastal Management 25:31-51.

Wood, L., L. Fish, J. Laughren, and D. Pauly. 2008. Assessing progress towards global marine protection targets: shortfalls in information and action. Oryx 42 340-351. 